\title{
Az akut szívelégtelenség korszerú kezelése a 2016-os ESC ajánlás tükrében
}

\author{
Zima Endre
}

\author{
Semmelweis Egyetem, Városmajor Szív- és Érgyógyászati Klinika, Budapest \\ Levelezési cím: \\ Dr. Zima Endre, 1122 Budapest, Városmajor u. 68. E-mail: zima.endre@gmail.com
}

\begin{abstract}
Az akut szívelégtelenség (ASZE) definíciója keringési elégtelenség olyan gyors és progresszív megjelenése, amely sürgető kórházi felvételt, diagnosztikai eljárásokat és azonnali ellátást igényel. Az ASZE lehet újkeletű vagy visszatérő, krónikus szívelégtelenség talaján. A nyugati országokban a kórházi felvételek egyik leggyakoribb oka az ASZE a 65 év feletti populációban. Az ASZE kórházi halálozása elérheti a 10\%-ot, kivéve a kardiogén sokkos betegeknél, akiknél a mortalitás 40-50\%. Az ASZE speciális patofiziológiai változásai progresszíven rontják a hemodinamikai állapotot, vesefunkciót, célszervek funkcióit. Az elsődleges ellátás során előtérbe került a beteg akut állapotfelmérésében a két alapvető életfontosságú szervrendszer, a keringési és légzőrendszer. Ha fennáll, elsődleges a kardiogén sokk kezelése inotrópokkal, vazopresszorokkal, és terápia-refrakter esetben adjuváns mechanikus keringéstámogatással. Egyidejüleg fennálló légzési elégtelenség súlyosságtól függően gyorsan és aggresszívan kezelendő oxigénadagolással, non-invazív vagy invazív pozitív nyomású lélegeztetéssel.

Stabilizációt és tünetek enyhítését követően a klinikai állapotfelmérés a perifériás keringés minőségét és a szöveti pangás meglétét-hiányát veszi alapul, amelyre alapozva kell megkezdeni a kongeszció csökkentését, a perfúzió javítását célzó kezelést. A legrosszabb klinikai állapotú beteg a „nedves” és „hűvös”, azaz a kardiogén sokkos beteg.

Ez esetben inotropok, Ca-érzékenyítő, vazopresszor kezelés mellett mechanikus keringéstámogatás is megfontolandó, szelektált betegpopulációban (ECLS, ECMO, VAD). Utóbbi a szívelégtelenség „híd” terápiája. Az új ajánlás egyik további nagyon fontos üzenete: amennyiben a betegnél nem ál fenn tünetes hipotónia, bradycardia vagy kardiogén sokk, a beteg által rendszeresen szedett bétareceptor-blokkoló kezelés folytatandó. Az ASZE miatt kórházba felvett betegeknél a bétareceptor-blokkoló kihagyása egyértelműen magasabb kórházi halálozással és rövidtávú mortalitással jár együtt.

Kulcsszavak: akut szívelégtelenség, gyógyszeres keringéstámogatás, eszközös keringés- és légzéstámogatás, szervpótló kezelés, szívtranszplantáció
\end{abstract}

\begin{abstract}
Up-to-date treatment of acute heart failure based on the ESC 2016 guideline
Acute heart failure (AHF) is by definition the rapid appearance and progression of circulatory failure that requires urgent hospital admission, evaluation and immediate interventions. It can be new onset or recurrence of symptoms and signs of heart failure. AHF is one of the most common cause of admission to hospital in people older than 65 years. In-hospital mortality of AHF is near $10 \%$ except cardiogenic shock that refers for $40-50 \%$ of mortality. AHF exerts specific pathophysiology impairing haemodynamics, renal function, and end-organ function. Most important change in the first line treatment is to assess and treat cardiogenic shock and respiratory failure on a fast and aggressive manner. After stabilisation and relief of symptoms one must do the physical examination that remains important for diagnosis and tailored treatment, focusing particularly on the signs of congestion and hypoperfusion. Characterizing the wet vs dry and cold vs warm clinical presentation the basic urgent therapy can be established to decrease congestion, increase perfusion. The worst case scenario is the wet and cold such as cardiogenic shock patient. Hereby beside inotropes, Ca-sensitizers, vasopressors and even mechanical circulatory support (ECLS, ECMO, VAD) in selected patient population is to be considered. Latter is called bridge therapy in HF. One more important message is given by the new guideline: if the patient with AHF does not represent symptomatic hypotension, bradycardia or cardiogenic shock, he should continue taking $\beta$ blockers. Discontinuation of $\beta$ blockers in AHF patients admitted to hospital was associated with significantly increased in-hospital mortality, short-term mortality.
\end{abstract}

Keywords: Acute heart failure, pharmacologic circulatory support, mechanical circulatory support, organ-replacement therapy, heart transplantation 
A szívelégtelenség (SZE) olyan komplex klinikai tünetegyüttes, amelyet strukturális (pl. myocardium-károsodás, vitium) vagy funkcionális (pl. volumen-, nyomás-túlterhelés, aritmia miatti) kardiális diszfunkció okozhat. Ezzel csökken a kamra pumpafunkciója (csökkent ejekciós frakciójú [EF], szisztolés SZE) és/vagy telődési képessége (megtartott EF-jú, diasztolés SZE), és típusos klinikai tünetekkel és fizikális jelekkel jár.

Az SZE-betegek tüneteik alapján állapotsúlyossági csoportokba oszthatóak az American College of Cardiology/American Heart Association, illetve a New York Heart Association stádiumbeosztása alapján.

ACC/AHA stádiumbeosztás:

- Stage A: SZE szempontjából magas rizikójú, de még strukturális szívbetegség és tünet nélküli beteg (hipertónia, diabétesz, obesitas, metabolikus szindróma, kardiotoxikus gyógyszerek).

- Stage B: Strukturális szívbetegség, de SZE tünetei nélkül (korábbi miokardiális infarktus, bal kamrai remodelling balkamra-hipertrófiával, csökkent EF, tünetmentes billentyübetegség).

- Stage C: Strukturális szívbetegség, korábbi vagy fennálló SZE tüneteivel.

- Stage D: Refrakter SZE, amely speciális (gyógyszeres és eszközös) beavatkozásokat igényel.

NYHA stádiumbeosztás:

- NYHA I.: Tüneteket csak normál egyéneknek is megterhelő fizikai aktivitás okoz, normál aktivitás nem okoz panaszt (palpitációt, diszpnoét, fáradtságot).

- NYHA II.: Fizikai aktivitás minimálisan korlátozott, normál fizikai megterhelés panaszokat okoz, de nyugalmi panasz nincs.

- NYHA III.: Nyugalmi panasz nincs, de normálisnál kisebb megterhelésre is panaszok.

- NYHA IV.: Nyugalmi panaszok, a legkisebb fizikai terhelés is panaszokat okoz.

Az akut esetek e klinikai klasszifikációk szerint leginkább a C és D, illetve NYHA IV. osztályba tartoznak.

\section{Az akut szívelégtelenség klinikai megjelenése}

Az akut SZE (ASZE) a szívelégtelenség tüneteinek gyors megjelenése vagy progressziója, ami azonnali beavatkozást igényel, azaz a szív bármely okú, rapid funkcióromlása miatt kialakuló, szöveti hipoperfúzióval, emelkedett pulmonalis kapilláris éknyomással, szöveti pangással járó, gyorsan progrediáló keringési elégtelenség.

Az akut balszívfél-elégtelenség típusos tünetei a bal szívfél előreható hibájából adódóan hipotenzió, centralizált keringés, márványozott, sápadt és hideg, cianotikus végtagok, akrák, valamint a hátraható hibából adódóan a minimális terhelésre vagy nyugalomban is jelentkező dyspnoe, orthopnoe, pulmonalis ödéma, Cheyne-Stokes-légzés, köhögés, köpet, sípolás-bugás („cardiac asthma”).
Az jobbszívfél-elégtelenség jelei a telt vena jugularis externa, a hepatomegália („kardiális cirrózis”), folyadékretenció (pl. anasarca).

A progressziót elsősorban két faktor határozza meg: az alapbetegség és a mellette kialakult keringési elégtelenség miatt kórosan túlaktiválódó neurohumorális kompenzatórikus mechanizmusok (endogén katekolaminok, renin-angiotenzin-aldoszteron-rendszer). További állapotromlás oka lehet a hátra- és előreható hiba miatt a teljes szervezet oxigénellátottságának és -igényének az egyensúlyzavara, amely metabolikus és akár kevert acidózist okozhat.

Az ASZE lehet de novo tünetegyüttes vagy krónikus SZE akut dekompenzációja is. A klinikai kép alapján az egyes formák átfedést mutathatnak, a klasszifikáció megkülönbözteti a heveny dekompenzált SZE-t, a pulmonalis ödémát, az alacsony perctérfogattal járó súlyos kardiogén sokkot, a hipertóniához társuló SZE-t, jobbszívfél-elégtelenséget, és magas perctérfogattal járó SZE-t.

Oka lehet strukturális szívbetegség (elsődlegesen akut koronária szindróma, krónikus iszkémia, idiopátiás vagy toxikus non-iszkémiás dilatatív cardiomyopathia, hipertónia, endo/myocarditis, akut billentyüelégtelenség) talaján kialakuló szisztolés, diasztolés vagy kevert miokardiális diszfunkció. Okozhatja a perctérfogat-csökkenést brady- vagy tachyarrhythmia, kamrai szeptumdefektus, tamponád, ugyancsak a bal vagy jobb szívfél utóterhelésének (pl. pulmonalis embólia) vagy előterhelésének ( $p l$. folyadék túltöltöttség, gyógyszerkihagyás, sönt) hirtelen növekedése. Extrakardiális rendszerbetegség pl. anémia, szepszis, veseelégtelenség, drog abúzus, thyreotoxicosis is okozhat ASZE-t a metabolikus igény-kínálat egyensúlyzavara révén.

Amennyiben nem avatkozunk be idejében, a keringési elégtelenség circulus vitiosusa alakul ki, a hipotónia-hipoperfúzió szív önnön vérellátását is rontja, ezzel a célszervek vérellátási zavara mellett a szív kontraktilis ereje is csökkenni fog.

\section{Az ASZE incidenciảja}

A SZE incidenciája 1-5/1000 fö, prevalenciája 0,1\% 50 év alatt, $6-10 \% 70$ felett. A SZE mortalitása az effektív kezelés mellett is magas, 5 éven belül akár $60 \%$ is lehet.

FINN-AKVA-tanulmány alapján a nóvum ASZE és az akut dekompenzált krónikus SZE megjelenése 1:1 arányú, ugyanezt igazolták HFREF (szisztolés) vs. HFPEF (diasztolés) megjelenésének arányában is. Klinikai megjelenésében dekompenzált szívelégtelenség és pulmonalis ödéma uralja a képet (mintegy 63\% és $26 \%$ ), míg a kardiogén sokk 2,3\%-ban, jobbszívfél-elégtelenség mintegy 5\%-ban fordult elő. A 3580 beteget bevonó Euro Heart Survey II és az 5533 beteget felmérő ALARM-HF-vizsgálatok is a vezető klinikai 
képként az akut dekompenzált szívelégtelenséget és a tüdőödémát igazolták együttesen, de a két vizsgálat között szignifikánsan eltért a pulmonalis pangás (16\% vs. $35 \%$ ) és a kardiogén sokk ( $4 \%$ vs. $11 \%$ ) előfordulási gyakorisága $(1,2,3)$.

A nyugati országokban a kórházi felvételek 9-10\%-a ASZE miatt történik, és 65 éves életkor felett ez a legygyakoribb ok, amely jelentős költségvonzattal bír a kórházak számára. Az USA-ban évente 7 millió beteget hospitalizálnak akut szívelégtelenség miatt (4).

Az ASZE kórházi halálozása a legkorszerübb kezelés mellett is akár $8-10 \%$, míg a legsúlyosabb formája, a kardiogén sokké 40-50\%. Az ASZE 6 és 12 hónapos mortalitása pedig $30 \%$, illetve $40 \%$ is lehet. A magas mortalitás mellett a betegek életminősége is romlik. Az ASZE miatt hospitalizált betegek 30-50\%-a optimalizált gyógyszeres kezelés mellett is 2-6 hónapon belül ismét kórházba kerül. Az idősödő betegpopuláció 70-80\%-a többér-betegséggel, számos társbetegséggel bír.

Az ESC 2016-os ajánlás egyértelmüen meghatározza az ASZE-kezelés lehetőségeit, amelynek alapja a beteg állapotának gyors felmérése, stabilizálása és az etiológiai háttér megállapításán alapuló oki kezelés (5).

\section{A kezdeti állapotfelmérés alapja a klinikai megítélés}

Az ASZE-nél is alkalmazunk stádiumbeosztást. Invazív hemodinamikai mérésekre alapozott stádiumbeosztást Killip alapozta meg infarktusos betegeknél: az I-es stádium a SZE nélküli beteget, a IV-es stádium a súlyos kardiogén sokkos beteget jelöli. Ez az eljárás egyszerủen és gyorsan nem kivitelezhetö, csak avatott kézben biztonságos és pontos a mérés.

Az új rizikó-stratifikáció a klinikai állapotfelmérésben a perifériás keringés minőségét és a szöveti pangás meglétét-hiányát veszi alapul. A rossz perifériás (azaz centralizált) keringésű, tüdőödémás, periférián is pangó beteg a legrosszabb prognózisú, míg a meleg, szá-

PANGÁS $(+)$

Tüdőpangás,orthopnoe, éjszakai dyspnoe, perifériás ödéma, telt nyaki vénák, pangásos hepatomegalia, PANGÁS (-) bélpangás, ascites hepatojuguláris reflux

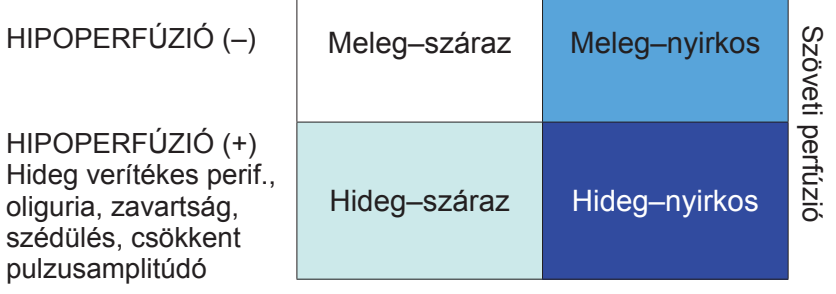

Pulmonalis pangás

1. ÁBRA. Egyszerű klinikai állapotfelmérés pangás és hipoperfúzió megítélésére alapozva raz bőrü, „tiszta” tüdejủ beteg a legjobb állapotú és kimenetelü beteg (1. ábra).

Az intenzív terápiás és kardiológus szakértői csoport konszenzusa alapján az ESC 2016-os irányelve is elötérbe helyezte a beteg akut állapotfelmérését két alapvető életfontosságú szervrendszer, a keringési és légzőrendszer szempontjából. Az ajánlás logikusan kihangsúlyozza, hogy amennyiben e két rendszer bármelyike életet veszélyeztetően elégtelen müködésü, azonnali terápia megkezdendő, és csakis a beteg stabilizálása után vagy azzal párhuzamosan szabad az etiológia keresését kezdeni. Elsődlegesen a kardiogén sokkot kell kezelni. Amennyiben a beteg már e rapidan progresszív ASZE-stádiumban van, haladéktalan sokktalanítás javallt inotrópokkal, vazopresszorokkal, és terápiarefrakter esetben adjuváns mechanikus keringéstámogatással (Id. később).

Légzési elégtelenség progressziója/megléte esetén haladéktalan légzéstámogatás megkezdendő, előbb oxigénadagolással, súlyos légzési elégtelenség esetén non-invazív, pozitív nyomású lélegeztetés (CPAP, BiPAP) megpróbálható, azonban kevert légzési elégtelenség, acidózis esetén az invazív lélegeztetéssel tudjuk a gázcserét adekvátan biztosítani. A noninvazív légzéstámogatás során az arcra igazított szoros maszkot a betegek egy része nem tudja magán elviselni. Az invazív lélegeztetés elönye a betegnél a biztos légút, a jobban kontrolálható gázcsere, a beteg légzési munkájának csökkentése, és nem utolsó sorban lélegeztetéssel obligát együttjáró szedáció pedig a beteg komfortját növeli (2. ábra) (5).

Az azonnali ellátás célja a tünetek kezelése, a szervezet kielégítő perfúziójának és oxigenizációjának viszszaállítása, a kardiális/renális károsodás megállítása, és ezekkel az ITO tartózkodási idő minimalizálása. A kórházi további ASZE-progresszió rosszabb kimenetelü mind kórházban tartózkodás alatt, mind elbocsátás után (6).

Amint a beteg stabilizálható, az új ajánlásban megint csak az egyszerüségre törekedtek: egy CHAMP rövidítésben összefoglalták az összes tisztázandó okot az ASZE hátterében: „C” az akut Coronaria szindrómát, „H” a Hipertenzív krízist, „A” az Aritmiát, „M” az akut Mechanikus okot, „P” a Pulmonalis embóliát jelöli. A CardShock vizsgálat kardiogén sokkos betegeknél 81\%-ban igazolt akut koronária szindrómát (7). Az ASZE-t a kiváltó oka szerint a patofiziológiának megfelelően progresszíven gyógyszeresen és eszközösen kezelni. Diagnosztikai lehetőségeink tárháza a fizikális vizsgálat mellett a 12 elvezetéses EKG (a szívritmuszavarok, szívfrekvencia, QRS-morfológia és iszkémiás jelek meghatározása), vérgázanalízis, vér laborvizsgálata az egyes szervi alapbetegségek (kardiális nekroenzimek, D-dimer, elektrolitok, vese-, máj-, pajzsmirigyfunkció, vérkép, natriuretikus peptidek), illetve gyógyszerhatások (pl. iatrogén hyperkalaemia) meghatározására. Amennyiben az akut szívelégtelenséggel 


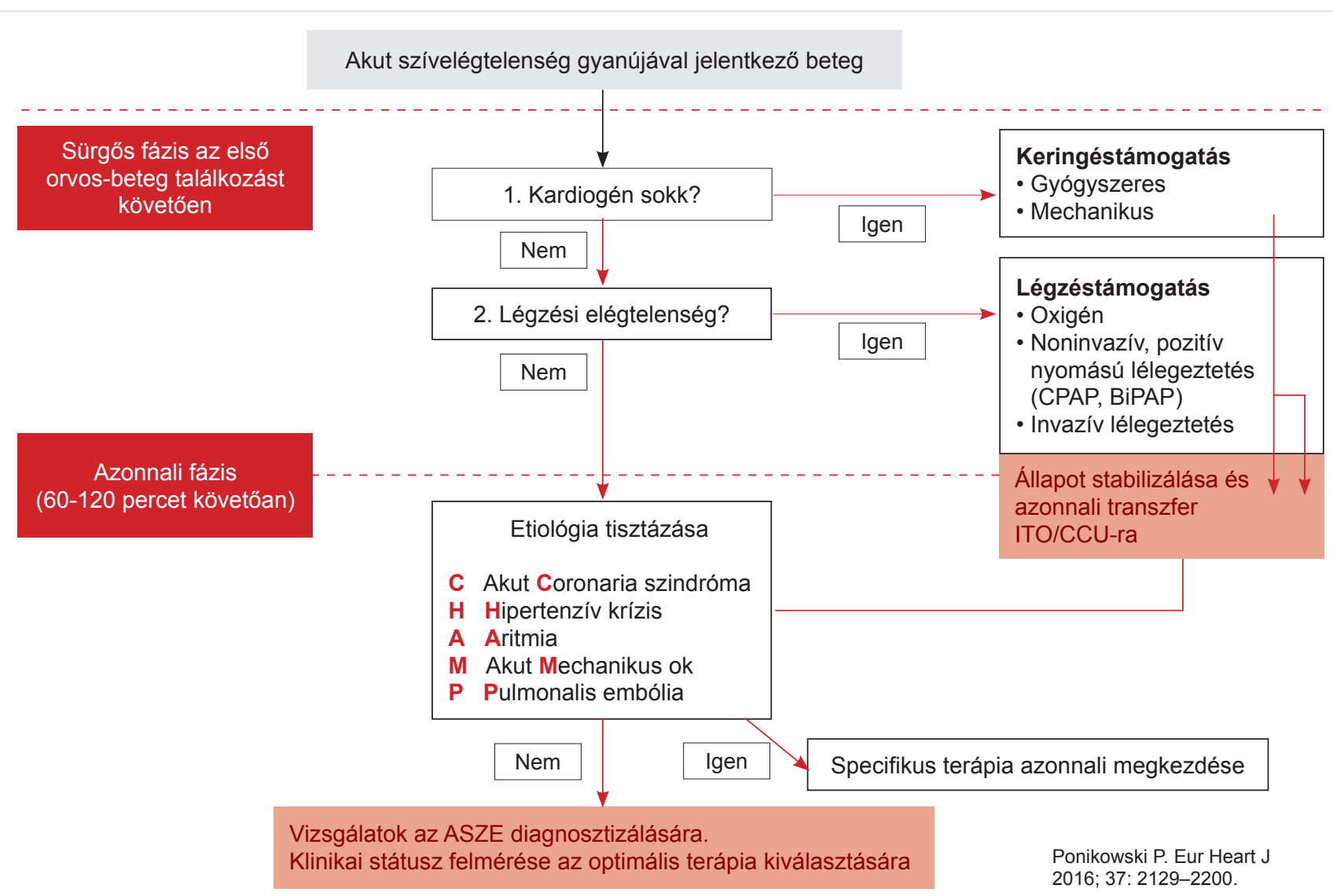

2. ÁBRA. Akut szívelégtelenség gyanúját keltő beteg ellátási és diagnosztikai algoritmusa

együtt célszerv-károsodást is jeleznek az emelkedett markerek, úgy, mint a kardiális troponin, a transzaminázok, vesekárosodás markerei, a betegnél magasabb halálozási aránnyal kell számolnunk (8).

Képalkotók segítik a diagnosztikát: a transthoracalis echokardiográfia (a szív strukturális és funkcionális eltéréseinek megítélése), mellkas-röntgenvizsgálat (kardiomegália, pleuralis fluidum, pangás, pneumónia, térfoglalás), koronarográfia, CT-angiográfia (pulmonalis embolizáció, akut aortabetegség).

Az ASZE-beteget szorosan monitorozni kell: vérnyomás, szívritmus, szívfrekvencia, perifériás oxigénszaturáció, klinikai jelek értékelése és rendszeres újraértékelése szükséges a terápiavezetéshez. Nincs konszenzus arra, hogy milyen invazivitással, menynyire agresszíven kell a betegek állapotát monitorozni és újraértékelni. Abban sincs konszenzus, hogy a pulmonalis artériás katéterezés valóban hozzá tud-e rutinszerűen tenni a diagnosztikus eljárások kapcsán a döntéshez szükséges adatokhoz. Mindemellett megjegyzendő, hogy csak „szakavatott kézben” ad pontos értékeket és alacsony a szövődményráta. Az intenzív társaságok szemszögéből a volumetriás monitorozásnak is van létjogosultsága, amely könnyebb felhasználást ad a kezünkbe, azonban az eredmények interpretációja kevésbé felhasználófüggő.

\section{Az akut szívelégtelenség gyógyszeres kezelése}

Noha a krónikus SZE oki kezelése mellett a túlaktiválódó neurohumorális szabályozási rendszer gyógyszeres gátlását is célozza a szimpatikus idegrendszer, reninangiotenzin-aldoszteron-szisztéma és az antidiuretikus rendszer gátlásával, az akut szakban a gátlás nem érvényesülhet, mert célunk a keringés gyógyszeres fenntartása, azaz az inotrópia, és a vazoreaktivitás növelése.

Általánosságban az ASZE és pulmonalis kongeszció gyógyszeres kezelésében a jelenleg elsőként választandó gyógyszerek a intravénás kacsdiuretikumok (pangás, ödéma kezelése), és az oxigén (hipoxia rendezése). A vazodilatátorok a szívelégtelenséggel együttjáró artériás és vénás vazokonstrikció miatt élveznek létjogosultságot, amennyiben hipotónia nem kontraindikálja alkalmazásukat. A diuretikumok elsősorban a RAAS-túlaktiváció miatti folyadékretenció miatt alkalmazandóak. Nincs különbség a bólusban vagy perfúzorban alkalmazott diuretikus terápia hatékonyságában (9), és megfontolható a kacsdiuretikum tiaziddal vagy spironolaktonnal való kombinációja refrakter ödéma esetén, noha utóbbiak hatása elsősorban KSZE-ben érvényesül. Diuretikum-refrakter hipervolémia esetén 
az ultrafiltráció is akut alternatíva, azonban jelenleg is vita tárgyát képezi a hatékonysága, a CARESS-vizsgálat nem igazolta az ultrafiltráció addicionális hatásosságát (10). Megfontolható az istabil keringésű betegeknél a szeptikus sokkban már bevált folyamatos 24-72 órás ultrafiltrációs kezelés, amely kis intravaszkuláris volumeningadozásokat okoz, kevésbé veszélyeztetve a keringést.

Az anxietas, légzési disztressz, diszpnoe kezelésére használt intravénás opiátok adagolását csak óvatossággal és szelektált esetekben javasolja az ajánlás, elsősorban légzés depresszív hatása miatt, de hányingert is okozhat, amely az izommunkát is emeli, aspirációveszéllyel is járhat (11).

Az ágymelletti állapotfelmérés a hemodinamikai státusz megítélése céljából a fent leírt, szöveti perfúzió és pangás együttes megítélését alkalmazó klinikai besorolás (hideg-meleg, nedves-száraz) alapján határozza meg a gyógyszeres kezelési stratégiánkat.
Nem pangó, jó szöveti perfúziójú betegnél a per os kezelés elegendő. Nem pangó, de rosszul perfundált betegnél („száraz és hűvös”) a csökkent perfúzió és hipovolém állapot rendezendő, első lépésben folyadékpótlással, majd esetlegesen inotróp szer beállítással. Amennyiben a betegnél pangás fennáll, de még adekvát szöveti perfúziója van, vaszkuláris vagy kardiális típusú megjelenés esetén is a vazodilatátorok és diuretikumok adandóak, terápia-refrakteritás esetén ultrafiltrációval lehet a folyadékretenciót csökkenteni. A „nedves és hideg”, pangó, centralizált keringésű, de még 90 Hgmm feletti vérnyomású beteg esetén vazodilátorok megfontolhatóak, diuretikumok és refrakter állapotban inotróp ágensek adandóak. Fontos kiemelni, hogy a nem kardiogén sokkos, de akut szívelégtelen beteg esetében a béta-blokkolók elhagyása nem javasolt, sőt káros, mivel a rebound effektus miatt a mortalitást bizonyítottan növeli a kórházi és a rövidtávú halálozást, illetve a rehospitalizációs rátát (12).

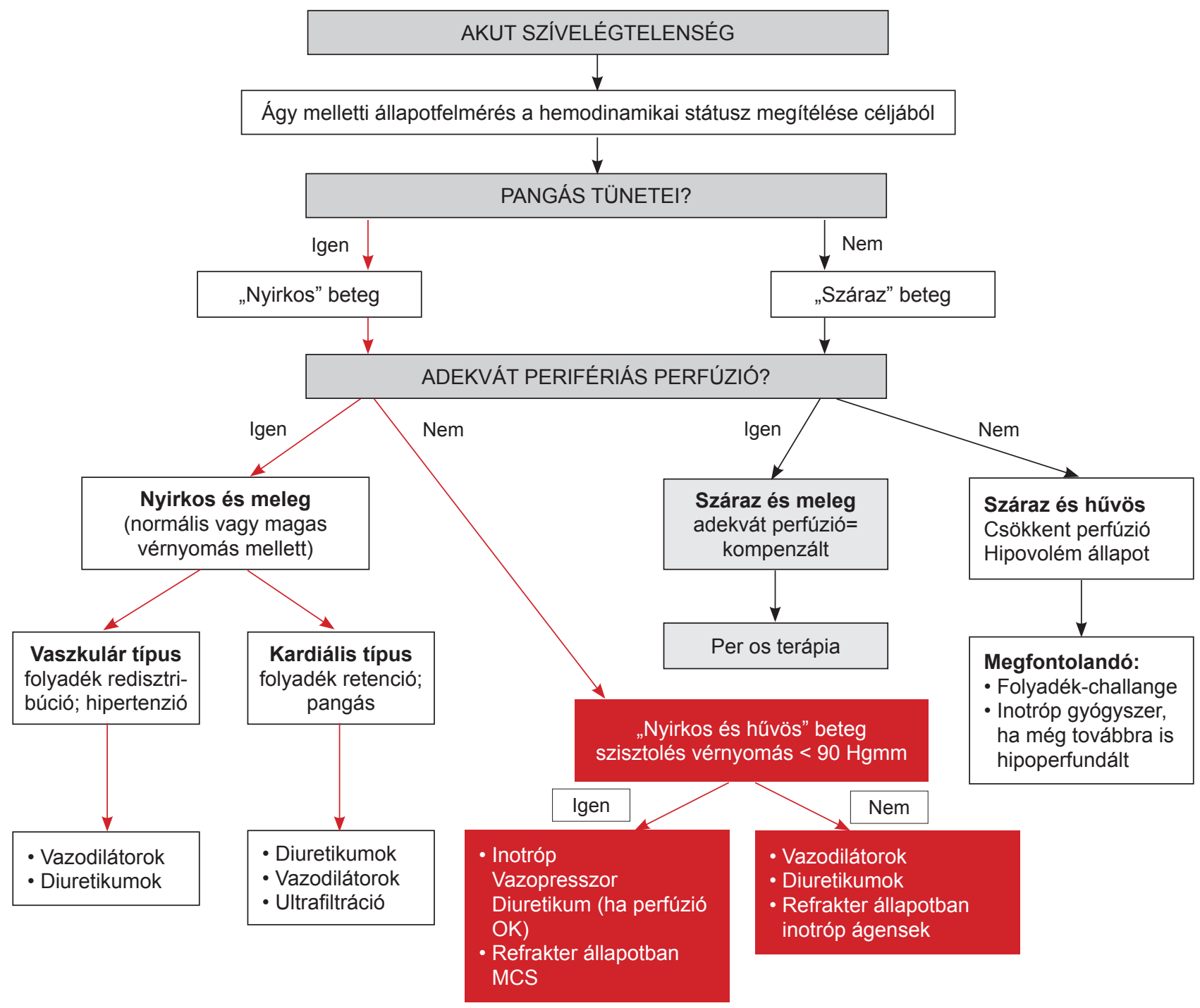

3. ÁBRA. ASZE korai kezelése a klinikai megjelenés, pangás tünetei alapján 
Kardiogén sokkos, 90 Hgmm alatti tenziójú betegnél a béta-blokkolók és vazodilatátorok elhagyása indokolt, és pozitív inotróp, vazopresszor, diuretikum adandó (utóbbi akkor, ha a perfúzió rendezhető), azonban refrakter állapotban mechanikus keringéstámogatás igénye gyorsan eldöntendő (IABP, extrakorporális membrán oxigenátor, illetve múszív-kezelés). A mechanikus keringéstámogatással párhuzamosan a szívtranszplantációs előkészítés megfontolása javasolt meghatározott kritériumoknak megfelelően.

Az ajánlás szerint inotrópok rövid távú intravénás alkalmazása megfontolandó $90 \mathrm{Hgmm}$ alatti szisztolés vérnyomás esetén és/vagy hipoperfúzió jelei esetén a perctérfogat és vérnyomás emelésére, perifériás perfúzió javítására és a szervfunkciók fenntartására. Béta-blokkoló kezelés alatt álló betegnél levosimendan vagy foszfodieszteráz (PDE) III-inhibitor intravénás adása megfontolandó béta-blokád hatásának ellensúlyozására, ha béta-blokád okozta hipotónia feltételezhető a hipoperfúzió hátterében. Mindkét szer vazodilatatív hatással bír, szoros EKG- és vérnyomás-monitorozás szükséges.

Mindemellett fontos megjegyezni, hogy a katekolaminok hosszú távú alkalmazása ismerten magasabb mortalitással jár együtt. Ennek oka a katekolaminok okozta potenciális proaritmia, szupraventrikuláris és kamrai aritmia, a tachycardia okozta miokardiális iszkémia és a következményes balkamra-diszfunkció progressziója. A katekolaminok indukálta miokardiális kalcium overload következménye az apoptotikus folyamatok felgyorsulása a szívizomszövetben $(12,13,14)$.

Ennek ellenére a jelenlegi egyetlen gyógyszeres lehetőségünk az inotrop és vazopresszor kombinált használata a kardiogén sokk kezelésében a perfúzió javítására $(5,15,16)$. Egy randomizált vizsgálat bizonyította noradrenalin szuperioritását a dopaminnal szemben kardiogén sokkos betegpopulációban. Utóbbi mind a mortalitást, mind az aritmiák előfordulását szignifikánsan növelte. Kardiogén sokkban, illetve kevésbé súlyos szívelégtelenségben, amennyiben a hipoperfúzióban a korábban optimális dózisra beállított, feltitrált béta-blokkoló kezelés is felelős lehet, levosimendan kezelés megfontolandó, mivel e kalciumérzékenyítő nem a béta-receptorokon keresztül, azaz nem a cAMP-útvonalon fejti ki pozitív inotróp hatását $(17,18)$. A PDE III-inhibitorok is szerepelnek az ajánlásban katekolamin refrakter, non-iszkémiás alapú szívelégtelenség kezelésének alternatívájaként, azonban ezek hosszú távú alkalmazása a mortalitást növeli, és csak korlátozottan hozzáférhető hazánkban (5).

\section{További kiegészítő gyógyszeres kezelési lehetóségeink}

Tromboembólia profilaxis (pl. LHWH) nem antikoagulált beteg esetén indokolt. Pitvarfibrilláció esetén a kamrai ritmus kontrolljára digoxin és/vagy béta-blokkoló megfontolandó elsővonalbeli szerként (utóbbi ASZE-ben csak stabilizálást követően adható!), és amiodaron is megfontolandó. Akut koronária szindrómához társuló ASZE és pitvarfibrilláció esetén a digitálisz adása fokozott óvatosságot követel, mindemellett e gyógyszer hangsúlyozottan nem alkalmas kardioverzióra. Akut szívelégtelenségben frekvenciakontrollra amiodaron adagolása is megfontolható. Amennyiben a magas kamrafrekvenciával járó pitvarfibrilláció etiológiai faktorként szerepel a szívelégtelenség progressziójában, urgens elektromos kardioverzió végzendő.

\section{Keringési elégtelenségben alkalmazható keringéstámogató eszközös kezelések (5)}

$A z$ intraaortikus ballonpumpa (IABP) kezelés konvencionális indikációja a mechanikus keringéstámogatás akut mechanikus szövődmény sebészeti megoldása alatti keringéstámogatás (pl. kamrai szeptumruptúra, akut mitralis regurgitáció), magas rizikójú reperfúziós kezelés ( $\mathrm{PCl}$ vagy $\mathrm{CABG}$ ) alatti keringéstámogatás, illetve súlyos myocarditis. Noha jelenleg az ajánlás a rutinszerú alkalmazást nem javasolja kardiogén sokkban, a legtöbb invazív kardiológiai centrumban csak ez az egyetlen módszer a mechanikus keringéstámogatás megoldására.

Azon betegeknél, akiknél szívelégtelenség vagy kardiogén sokk (INTERMACS I. szint) nem rendezhető intravénás gyógyszeres támogatással, perkután keringéstámogató eszközök, extarkorporális membrán oxigenátor (ECMO), extrakorporális life support (ECLS) beültetése megfontolandó a szív és/vagy a vitális célszervek funkciójavulásáig. Ezek rövidtávon alkalmazható eszközök. Hosszú távú keringéstámogatás lehetőségét nyújtja a bal-, jobb- vagy kétkamrai assist device (RVAD, LVAD, BiVAD). Ezen eszközök úgynevezett „bridge” terápiás lehetőségek, amelyek időnyerést biztosítanak a beteg és ellátói számára, hogy a további terápiás lehetőségeket eldöntsék. A „bridge” lehet áthidaló megoldás döntéshozatalig vagy egy másik, hosszabb távú keringéstámogatásig (bridge-to-decision, illetve bridgeto-bridge), lehet híd a szívtranszplantációig (bridge to transplant), a gyógyulásig (bridge-to-recovery), vagy - elsősorban a tehetősebb egészségügyi finanszírozással bíró nyugati országokban végleges (destination therapy) megoldás is. E kezelési modalitások közül hazánkban az ECMO több egyetemi és egy országos kardiológiai centrumban hozzáférhető, de a VAD-kezelés mindössze 2 vezető centrumban kerül beültetésre.

\section{Irodalom}

1. Siirilä-Waris K, Lassus J, Melin J, et al. FINN-AKVA Study Group. Characteristics, outcomes, and predictors of 1-year mortality in patients hospitalized for acute heart failure. Eur Heart J 2006; 27: 3011 7. DOI: https://doi.org/10.1093/eurheartj/eh|407

2. Nieminen MS, Brutsaert D, Dickstein K, et al. EuroHeart Survey Investigators; Heart Failure Association, European Society of Car- 
diology. EuroHeart Failure Survey II (EHFS II): a survey on hospitalized acute heart failure patients: description of population. Eur Heart J 2006; 27: 2725-36. DOI: https://doi.org/10.1093/eurheartj/ehl193 3. Follath F, Yilmaz MB, Delgado JF, et al. Clinical presentation, management and outcomes in the Acute Heart Failure Global Survey of Standard Treatment (ALARM-HF). Intensive Care Med 2011; 37: 619-26. DOI: https://doi.org/10.1007/s00134-010-2113-0

4. Mozaffarian D, Benjamin EJ, Go AS, et al. Heart disease and stroke statistics - 2016 update: a report from the American Heart Association. Circulation 2016; 133: e38-360. DOI: https://doi.org/10.1161/ CIR.0000000000000350

5. Ponikowski P, Voors AA, Anker SD, et al. 2016 ESC guidelines for the diagnosis and treatment of acute and chronic heart failure: the Task Force for the diagnosis and treatment of acute and chronic heart failure of the European Society of Cardiology (ESC). Developed with the special contribution of the Heart Failure Association (HFA) of the ESC. Eur J Heart Fail 2016; 18: 891-975. DOI: https:// doi.org/10.1093/eurheartj/ehw128

6. Butler J, Gheorghiade M, Kelkar A, et al. In-hospital worsening heart failure. Eur J Heart Fail 2015; 17: 1104-13. DOI: https://doi. org/10.1002/ejhf.333

7. H arjola VP, Lassus J, Sionis A, et al. CardShock Study Investigators; GREAT network. Clinical picture and risk prediction of shortterm mortality in cardiogenic shock. Eur J Heart Fail 2015; 17: 5019. DOI: https://doi.org/10.1002/ejhf.260

8. Metra M, Cotter G, Davison BA, et al. Effect of serelaxin on cardiac,renal, and hepatic biomarkers in the relaxin in acute heart failure (RELAX-AHF) development program: correlation with outcomes. $J$ Am Coll Cardiol 2013; 61: 196-206. DOI: https://doi.org/10.1016/j. jacc.2012.11.005

9. Felker GM, Lee KL, Bull DA, et al. Diuretic strategies in patients with acute decompensated heart failure. N Engl J Med 2011; 364: 797-805. DOI: https://doi.org/10.1056/NEJMoa1005419

10. Bart BA, Goldsmith SR, Lee KL, et al. Cardiorenal rescue study in acute decompensated heart failure: rationale and design of CARRESS-HF, for the Heart Failure Clinical Research Network. J Card Fail 2012; 18: 176-82. DOI: https://doi.org/10.1016/j.cardfail.2011.12.009
11. Gheorghiade M, Follath F, Ponikowski P, et al. Assessing and grading congestion in acute heart failure: a scientific statement from the Acute Heart Failure Committee of the Heart Failure Association of the European Society of Cardiology and endorsed by the European Society of Intensive Care Medicine. Eur J Heart Fail 2010; 12 423-33. DOI: https://doi.org/10.1093/eurihf/hfq045

12. Prins KW, Neill JM, Tyler JO, Eckman PM, Duval S. Effects of beta-blocker withdrawal in acute decompensated heart failure: a systematic review and meta-analysis. JACC Heart Fail 2015; 3: 647-653. DOI: https://doi.org/10.1016/j.jchf.2015.03.008

13. Teerlink JR, Metra M, Zaca V, et al. Agents with inotropic properties for the management of acute heart failure syndromes. Traditional agents and beyond. Heart Fail Rev 2009; 14: 243-53. DOI: https://doi.org/10.1007/s10741-009-9153-y

14. De Backer D, Biston P, Devriendt J, et al. Comparison of dopamine and norepinephrine in the treatment of shock. N Engl J Med 2010; 362: 779-89. DOI: https://doi.org/10.1056/NEJMoa0907118

15. Collins SP, Storrow AB, Albert NM, et al. Early management ofpatients with acute heart failure: state of the art and future directions. A consensus document from the Society for Academic Emergency Medicine/Heart Failure Society of America Acute Heart Failure Working Group. J Card Fail 2015; 21: 27-43. DOI: https://doi.org/10.1016/j.cardfail.2014.07.003

16. Mebazaa A, Yilmaz MB, Levy $P$, et al. Recommendations on pre-hospital \& early hospital management of acute heart failure: a consensus paper from the Heart Failure Association of the European Society of Cardiology, the European Society of Emergency Medicine and the Society of Academic Emergency Medicine. Eur J Heart Fail 2015; 17: 544-58. DOI: https://doi.org/10.1002/ejhf.289

17. Russ MA, Prondzinsky R, Christoph A, et al. Hemodynamic improvement following levosimendan treatment in patients with acute myocardial infarction and cardiogenic shock. Crit Care Med 2007; 35: 2732-2739. DOI: https://doi.org/10.1097/01. CCM. 0000287524.17358 .48

18. Fuhrmann JT, Schmeisser A, Schulze MR, et al. Levosimendan is superior to enoximone in refractory cardiogenic shock complicating acute myocardial infarction. Crit Care Med 2008; 36: 22572266. DOI: https://doi.org/10.1097/CCM.0b013e3181809846

\section{MAGYAR HYPERTONIA TÁRSASÁG XXVI. TOVÁBBKÉPZÓ KONGRESSZUSA}

